Brit. J. industr. Med., 1965, 22, 305.

\title{
A SURVEY OF DUST CONCENTRATIONS IN FLAX MILLS IN NORTHERN IRELAND
}

\author{
BY \\ I. R. McAulay, G. C. R. CAREY, J. D. MERRETT, R. H. MCCLARIN, \\ P. C. ELWOOD, and J. PEMBERTON \\ From the Department of Social and Preventive Medicine, The Queen's University of Belfast
}

(RECEIVED FOR PUBLICATION DECEMBER 18, 1964)

The concentrations in the air of total and of respirable (less than 7 microns equivalent diameter) dust were measured in 142 workrooms of 17 Northern Ireland flax spinning mills using a hexhlet air sampler.

Neither the distribution of total nor of respirable dust concentrations ( $\mathrm{mg} . / 100 \mathrm{~m}^{3}$ air) measured in each of four large workrooms conformed to the normal (or Gaussian) distribution, but it is shown that the logarithms (to the base 10) of these concentrations are normally distributed. In order to make valid statistical comparisons between the dustiness of the different types of room, mean log. concentrations are therefore used.

The mean log. concentrations of total and of respirable dust, and the $95 \%$ confidence limits derived from these, were calculated for each room surveyed. For total and respirable dust the ranges of mean log. concentrations followed in brackets by the respective antilogs. (mg./100 m. ${ }^{3}$ air) were as follows:

\begin{tabular}{l|l|r}
\hline & Total Dust & Respirable Dust \\
\hline 33 Pre-preparing rooms & $1 \cdot 75-3 \cdot 47(56-2951)$ & $1 \cdot 68-2 \cdot 90(48-794)$ \\
55 Preparing rooms & $1 \cdot 54-2 \cdot 97(35-933)$ & $1 \cdot 43-2 \cdot 42(27-263)$ \\
22 Wet finishing rooms & $1 \cdot 40-2 \cdot 11(25-129)$ & $1 \cdot 09-2 \cdot 09(12-123)$ \\
32 Other finishing rooms & $1 \cdot 42-2 \cdot 43(26-269)$ & $1 \cdot 24-2 \cdot 32(17-209)$ \\
\hline
\end{tabular}

Thus, dust concentrations varied widely within each category of room, although in general the pre-preparing rooms had the highest levels followed by other preparing rooms, other finishing rooms, and wet finishing rooms, in that order.

In a previous paper (Elwood, Pemberton, Merrett, Carey, and McAulay, 1965) a survey of byssinosis and other respiratory symptoms in flax workers in Northern Ireland has been reported and the processes of flax preparing and spinning have been described.

The present paper gives an account of the environmental studies which were carried out as part of the survey and provides quantitative data concerning dust concentrations at various stages in the production of the finished yarn.

\section{Methods}

Estimation of Airborne Dust in Workrooms.-The technique used for the collection of total and respirable dust was similar to that described by Roach and Schilling (1960) using two Casella air-sampling hexhlet instruments modified to carry filter discs for collecting the dust instead of the customary soxhlet tube. The rate of flow of air was kept constant at $\mathbf{1 0 0}$ litres per minute through each instrument by means of a critical orifice, and the instruments were mounted horizontally about one metre above floor level.

The filter discs used at the beginning of the survey were $7 \mathrm{~cm}$. diameter circles of low-resistance, high-efficiency Tullis-Russell paper. During the survey this type of paper became unobtainable and it was necessary to change to Whatman No. 4 paper. This was tested and found to have a closely similar collection efficiency to that of Tullis-Russell paper, though it showed a greater tendency to clog when very dusty atmospheres were sampled. However, each sampling instrument was fitted with a gauge 
which showed the pressure drop across the critical orifice, and sampling was terminated whenever the gauge fell below a critical level of $100 \mathrm{~mm}$. of mercury, below which the constant air flow of 100 litres per minute was not maintained. A 50-minute sampling period was used in the first few mills surveyed but this was later reduced to 30 minutes. Shorter sampling times were used occasionally if dust concentrations were high and the paper became clogged.

The hexhlet dust samplers were fitted with a $2 \mathrm{~mm}$. mesh wire gauze through which air passed into the instrument. It was found that no coarse dust or long fibres (greater than $2 \mathrm{~mm}$. in size) collected on this outer gauze except in the case of seven samples in one very dusty breaker-card room where approximately $6 \%$ by weight of the total dust was found on the gauze; these coarse fibres were removed and weighed separately. In what follows, the amount of dust collected on the filter of the nonelutriated instrument is called 'total dust', corresponding to the 'medium' plus 'fine' dust categories of Roach and Schilling (1960). Only particles of less than 7 microns equivalent* diameter pass the elutriator. This fraction, termed 'fine' dust by Roach and Schilling (1960), we have called respirable dust since it is assumed that only particles of less than 7 microns diameter are likely to reach the terminal bronchioles and alveoli.

Filter discs were dried for 24 hours at $110^{\circ} \mathrm{C}$. and weighed before sampling. This procedure was repeated after sampling. The difference between these two weights gave the weight of dry dust in the volume sampled.

Sampling Within Mills.-Samples were taken during normal working hours on all days of the five-day working week, with the exception of Friday afternoons when cleaning down and re-setting of the machines normally took place. Each room to be sampled was measured and divided up into a number of uniform areas each of approximately $1,000 \mathrm{sq}$. feet. These areas were numbered serially, and the sampling order was determined by a random procedure. One pair of samples was taken in each area at a point where the minimum of obstruction was caused to workers. In a few instances it was impossible to position the sampling instruments in the selected area either because of insufficient room between

*Diameter of a spherical particle of unit density with the same settling velocity as the particle under consideration. the machines or because electric power points were not available.

Some processes, for example tow-mixing and breakercarding, are carried on intermittently, and some rooms were working well below capacity. The results for these rooms, if fully sampled as described, would tend to show an unrealistic distribution of sample readings. Samples were therefore not taken in rooms that were working at less than two-thirds capacity; in rooms working at capacities above this level, sampling was done only in those areas in which machines were actually operating.

Exclusion of Data.-At the beginning of the survey there were 20 mills in Northern Ireland known to be engaged in the spinning of flax or flax plus synthetic fibres. No clinical or environmental data are available for one of these mills, the management being unable to co-operate. The first mill surveyed was spinning flax only and has been excluded from the analysis since it was regarded as a pilot survey to enable dust sampling methods to be studied and standardized. Another mill spinning flax only had to be excluded as there were insufficient power points available for operation of the dust sampler. The data presented therefore relate to $\mathbf{1 4 2}$ rooms in 17 mills, 10 of which were spinning flax only, and seven flax plus synthetic fibres.

\section{Results}

Distribution of Sample Weights.-For a valid interpretation of means, standard deviations, and standard errors, it is necessary that the distributions of estimates of dust concentrations conform to the normal (or Gaussian) type of distribution. These distributions were examined in the few rooms where sufficient numbers of observations were available to make such a test realistic. The results given in Table 1 for total dust and for respirable dust show that sample weights were not normally distributed. Transformation of the original units $\left(\mathrm{mg} . / 100 \mathrm{~m}^{3}\right.$ air) to logarithms to the base 10 , however, gave frequency distributions which showed no significant* evidence of skewness or kurtosis; it was assumed

*The criterion of significance used throughout is $P<0.05$.

TESTS OF NORMALITY OF DISTRIBUTIONS OF DUST CONCENTRATIONS (mg./100 m. ${ }^{3}$ )

\begin{tabular}{|c|c|c|c|c|c|c|}
\hline \multirow{2}{*}{$\begin{array}{c}\text { Mill } \\
\text { and } \\
\text { Room }\end{array}$} & \multirow{2}{*}{$\begin{array}{c}\text { Variates } \\
\text { Examined }\end{array}$} & \multirow{2}{*}{$\begin{array}{c}\text { No. of } \\
\text { Observations }\end{array}$} & \multicolumn{2}{|c|}{ Total Dust } & \multicolumn{2}{|c|}{ Respirable Dust } \\
\hline & & & $\mathrm{g}_{1} \pm$ S.E. & $\mathbf{g}_{2} \pm$ S.E. & $\mathbf{g}_{1} \pm$ S.E. & $\mathrm{g}_{2} \pm$ S.E. \\
\hline $2 \mathrm{C}$ & $\begin{array}{l}\text { Original measurements } \\
\log _{10} \text { (original) }\end{array}$ & $\begin{array}{l}24 \\
24\end{array}$ & $\begin{array}{r}0.89 \pm 0.472 \\
-0.24 \pm 0.472\end{array}$ & $\begin{array}{r}0.30 \pm 0.918 \\
-0.33 \pm 0.918\end{array}$ & $\begin{array}{l}1.18^{*} \pm 0.472 \\
0.03 \pm 0.472\end{array}$ & $\begin{array}{r}0.01 \pm 0.918 \\
-0.28 \pm 0.918\end{array}$ \\
\hline $2 E / F$ & $\begin{array}{l}\text { Original measurements } \\
\log _{10} \text { (original) }\end{array}$ & $\begin{array}{l}24 \\
24\end{array}$ & $\begin{array}{l}3.48 * \pm 0.472 \\
0.44 \pm 0.472\end{array}$ & $\begin{array}{c}13.99 * \pm 0.918 \\
1.64 \pm 0.918\end{array}$ & $\begin{array}{r}1.04^{*} \pm 0.472 \\
-0.06 \pm 0.472\end{array}$ & $\begin{array}{l}0.47 \pm 0.918 \\
1.28 \pm 0.918\end{array}$ \\
\hline $\begin{array}{l}4 \\
I / J / K\end{array}$ & $\begin{array}{l}\text { Original measurements } \\
\log _{10} \text { (original) }\end{array}$ & $\begin{array}{l}30 \\
30\end{array}$ & $\begin{array}{l}2.02 * \pm 0.427 \\
0.21 \pm 0.427\end{array}$ & $\begin{array}{l}2.01^{*} \pm 0.833 \\
1.17 \pm 0.833\end{array}$ & $\begin{array}{l}1.02 * \pm 0.427 \\
0.57 \pm 0.427\end{array}$ & $\begin{array}{r}-3.56^{*} \pm 0.833 \\
0.25 \pm 0.833\end{array}$ \\
\hline
\end{tabular}

For normality $g_{1}$ and $g_{2}$ should be zero.

*Significantly different from zero at $\mathbf{P}<0.05$.

TABLE 1 
therefore that the logarithms of estimates of dust concentrations in $\mathrm{mg} . / 100 \mathrm{~m}^{3}$ within all rooms are normally distributed. The logarithms of the dust estimates are therefore used in all subsequent analyses. Arithmetic means of dust concentrations are not quoted in what follows because, even when the number of observations is large, the geometric mean of the sample weights may give an estimate of dustiness which may be considerably lower than the estimate given by the arithmetic mean. In room $2 \mathrm{E} / \mathrm{F}$, for example, where 24 observations were made the geometric mean gave an estimate of only $65 \%$ of the estimate given by the arithmetic mean. This suggests that in dust survey work the normality of distribution of dust concentrations in a room should always be examined if comparisons between rooms are to be made, and arithmetic means should be used only when the curve conforms to the normal distribution. Otherwise a few atypically high or low readings in a room may result in a misleading estimate.

Effect of Time on Sampling.-Dust samples were taken at different times and on different days of the week. In the carding room and three preparing rooms of one mill and in the preparing room of another mill, where sampling had continued for four days, it was possible to examine differences between samples taken in the mornings and afternoons on different days. The analysis of variance for these data on total and on respirable dust showed that there were no significant differences between either times of day or days of sampling (Table 2). It appeared valid therefore to estimate the mean level of airborne dust in each room (in log. units) irrespective of the time of sampling.

Levels of Dust in Different Rooms.-The rooms were grouped into four categories corresponding to the sequence of operations in a flax spinning mill: (1) 33 pre-preparing rooms (roughing, sorting, mixing, piecing, hackling, breaker-carding, and carding); (2) 55 other preparing rooms (combing, spreading, drawing, doubling, roving, and dry and gill spinning); (3) 22 wet finishing rooms (wet finishing and polishing); and (4) 32 other finishing rooms (reeling, winding, twisting, dyeing, drying, bundling, and packing).

A more detailed description of the processes involved in each of these four categories of room is given elsewhere (Elwood et al., 1965).

TABLE 2 ANALYSIS OF VARIANCE: RESPIRABLE DUST AND TOTAL DUST CONCENTRATIONS IN THREE FLAX

(mg. dust $/ 100 \mathrm{~m}^{3}$ air expressed as $\log _{10}$ )

\begin{tabular}{|c|c|c|c|c|c|c|}
\hline $\begin{array}{c}\text { Mill and } \\
\text { Rooms }\end{array}$ & $\begin{array}{l}\text { Source of } \\
\text { Variation }\end{array}$ & $\begin{array}{l}\text { Sum of } \\
\text { Squares }\end{array}$ & d.f. & $\begin{array}{c}\text { Mean } \\
\text { Squares }\end{array}$ & $\mathbf{F}$ & $\mathbf{P}$ \\
\hline \multirow[t]{2}{*}{$\begin{array}{c}\text { Respirable Dust } \\
\text { 2C }\end{array}$} & $\begin{array}{l}\text { Days } \\
\text { Times } \\
\text { Residual }\end{array}$ & $\begin{array}{l}0.31519 \\
0.01000 \\
0.66507\end{array}$ & $\begin{array}{r}4 \\
1 \\
13\end{array}$ & \multirow[t]{2}{*}{$\begin{array}{l}0.07880 \\
0.01000 \\
0.05116\end{array}$} & \multirow[t]{2}{*}{$<1^{1 \cdot 54}$} & \multirow[t]{2}{*}{$\begin{array}{l}0 \cdot 2-0 \cdot 3 \\
0 \cdot 2-0 \cdot 3\end{array}$} \\
\hline & Total & 0.99026 & 18 & & & \\
\hline \multirow[t]{2}{*}{$4 C$} & $\begin{array}{l}\text { Days } \\
\text { Times } \\
\text { Residual }\end{array}$ & $\begin{array}{l}0.03218 \\
0.02106 \\
0.21497\end{array}$ & $\begin{array}{r}3 \\
1 \\
11\end{array}$ & \multirow[t]{2}{*}{$\begin{array}{l}0.01073 \\
0.02106 \\
0.01954\end{array}$} & \multirow[t]{2}{*}{$<1.08$} & \multirow[t]{2}{*}{$\begin{array}{l}0 \cdot 2-0 \cdot 3 \\
0.2-0.3\end{array}$} \\
\hline & Total & $0 \cdot 26821$ & 15 & & & \\
\hline \multirow[t]{2}{*}{$\stackrel{4}{\mathbf{4} / \mathbf{J} / \mathrm{K}}$} & $\begin{array}{l}\text { Days } \\
\text { Times } \\
\text { Residual }\end{array}$ & $\begin{array}{l}0.02415 \\
0.00003 \\
0.25085\end{array}$ & $\begin{array}{r}4 \\
1 \\
13\end{array}$ & \multirow[t]{2}{*}{$\begin{array}{l}0.00604 \\
0.00003 \\
0.01930\end{array}$} & \multirow[t]{2}{*}{$\begin{array}{l}<1 \\
<1\end{array}$} & \multirow[t]{2}{*}{$\begin{array}{l}0 \cdot 2-0 \cdot 3 \\
0 \cdot 2-0 \cdot 3\end{array}$} \\
\hline & Total & 0.27503 & 18 & & & \\
\hline \multirow[t]{2}{*}{ Total Dust } & $\begin{array}{l}\text { Days } \\
\text { Times } \\
\text { Days } \times \text { Times } \\
\text { Residual }\end{array}$ & $\begin{array}{l}0.40418 \\
0.01304 \\
0.61140 \\
0.28255\end{array}$ & $\begin{array}{l}4 \\
1 \\
4 \\
9\end{array}$ & \multirow[t]{2}{*}{$\begin{array}{l}0 \cdot 10104 \\
0 \cdot 01304 \\
0 \cdot 15285 \\
0 \cdot 03139\end{array}$} & \multirow[t]{2}{*}{$\begin{array}{l}<1.22 \\
4.85\end{array}$} & \multirow[t]{2}{*}{$\begin{array}{l}0.05-0.1 \\
0.2-0.3 \\
0.01-0.05\end{array}$} \\
\hline & Total & 1.31117 & 18 & & & \\
\hline \multirow[t]{2}{*}{$4 C$} & $\begin{array}{l}\text { Days } \\
\text { Times } \\
\text { Residual }\end{array}$ & $\begin{array}{l}0.03752 \\
0.01179 \\
0.36860\end{array}$ & $\begin{array}{r}3 \\
11 \\
11\end{array}$ & \multirow[t]{2}{*}{$\begin{array}{l}0.01251 \\
0.01179 \\
0.03351\end{array}$} & \multirow[t]{2}{*}{$\begin{array}{l}<1 \\
<1\end{array}$} & \multirow[t]{2}{*}{$\begin{array}{l}0.2-0.3 \\
0.2-0.3\end{array}$} \\
\hline & Total & 0.41791 & 15 & & & \\
\hline \multirow[t]{2}{*}{$\begin{array}{c}4 \\
I / J / K\end{array}$} & $\begin{array}{l}\text { Days } \\
\text { Times } \\
\text { Residual }\end{array}$ & $\begin{array}{l}0.07549 \\
0.00147 \\
0.26049\end{array}$ & $\begin{array}{r}4 \\
1 \\
13\end{array}$ & \multirow[t]{2}{*}{$\begin{array}{l}0.01887 \\
0 \cdot 00147 \\
0.02004\end{array}$} & \multirow[t]{2}{*}{$\begin{array}{l}<1 \\
<1\end{array}$} & \multirow[t]{2}{*}{$\begin{array}{l}0.2-0.3 \\
0.2-0.3\end{array}$} \\
\hline & Total & 0.33745 & 18 & & & \\
\hline
\end{tabular}


TABLE 3

CONCENTRATION OF AIRBORNE DUST (TOTAL FRACTION) IN PRE-PREPARING ROOMS IN MILLS HANDLING FLAX OR FLAX PLUS SYNTHETIC FIBRES, BY TYPE OF ROOM. ROOMS RANKED BY MEAN DUST LEVEL

\begin{tabular}{|c|c|c|c|c|c|c|}
\hline \multirow{2}{*}{$\begin{array}{l}\text { Mill No. } \\
\text { and } \\
\text { Room Code }\end{array}$} & \multirow[b]{2}{*}{$\begin{array}{c}\text { Fibre } \\
\text { Handled }\end{array}$} & \multirow[b]{2}{*}{$\begin{array}{l}\text { Type of } \\
\text { Room }\end{array}$} & \multirow[b]{2}{*}{$\begin{array}{l}\text { No. of } \\
\text { Samples }\end{array}$} & \multicolumn{3}{|c|}{ Concentration of Airborne Dust (total) } \\
\hline & & & & $\begin{array}{c}\text { Mean* } \\
\text { log. }\end{array}$ & $\begin{array}{c}\text { S.D.* } \\
\text { of log. } \\
\text { Concentrations }\end{array}$ & $\begin{array}{l}95 \% \text { Confidence Limits } \\
\text { of Mean Concentrations } \\
\text { (mg. dust } / 100 \mathrm{~m}^{3} \text { air) }\end{array}$ \\
\hline $\begin{array}{rl}8 & \mathrm{D} \\
13 & \mathrm{C} \\
2 & \mathrm{~B} \\
23 & \mathrm{C} \\
12 & \mathrm{C} \\
8 & \mathrm{C} \\
2 & \mathrm{C} \\
8 & \mathrm{~A} \\
20 & \mathrm{C} \\
22 & \mathrm{C} \\
20 & \mathrm{~A} \\
18 \mathrm{~B} \\
4 & \mathrm{~A} \\
18 & \mathrm{D} \\
16 & \mathrm{~B} \\
4 & \mathrm{C} \\
4 & \mathrm{~K} \\
12 & \mathrm{~B} \\
10 \mathrm{C} \\
15 \mathrm{C} \\
13 \mathrm{~A} \\
14 \mathrm{~A} \\
4 \mathrm{~B} \\
12 & \mathrm{E} \\
18 \mathrm{C} \\
19 & \mathrm{~A} \\
8 & \mathrm{~B} \\
9 & \mathrm{~B} \\
22 & \mathrm{~A} \\
17 & \mathrm{~B} \\
14 & \mathrm{C} \\
9 & \mathrm{C} \\
15 & \mathrm{~A}\end{array}$ & $\begin{array}{l}\text { Flax } \\
\text { Flax } \\
\text { FS } \\
\text { Flax } \\
\text { Flax } \\
\text { Flax } \\
\text { FS } \\
\text { Flax } \\
\text { Flax } \\
\text { FS } \\
\text { Flax } \\
\text { Flax } \\
\text { Flax } \\
\text { Flax } \\
\text { Flax } \\
\text { Flax } \\
\text { Flax } \\
\text { Flax } \\
\text { FS } \\
\text { Flax } \\
\text { Flax } \\
\text { FS } \\
\text { Flax } \\
\text { Flax } \\
\text { Flax } \\
\text { FS } \\
\text { Flax } \\
\text { FS } \\
\text { FS } \\
\text { Flax } \\
\text { FS } \\
\text { FS } \\
\text { Flax }\end{array}$ & $\begin{array}{l}\text { Breaker card } \\
\text { Carding } \\
\text { Hackling } \\
\text { Carding } \\
\text { Carding } \\
\text { Carding } \\
\text { Carding } \\
\text { Roughing } \\
\text { Carding } \\
\text { Carding } \\
\text { Hackling } \\
\text { Hackling } \\
\text { Piecing } \\
\text { Carding } \\
\text { Hackling } \\
\text { Carding } \\
\text { Combing } \\
\text { Hackling } \\
\text { Carding } \\
\text { Carding } \\
\text { Hackling } \\
\text { Hackling } \\
\text { Hackling } \\
\text { Combing } \\
\text { Carding } \\
\text { Hackling } \\
\text { Hackling } \\
\text { Hackling } \\
\text { Hackling } \\
\text { Hackling } \\
\text { Carding } \\
\text { Carding } \\
\text { Hackling }\end{array}$ & $\begin{array}{r}2 \\
3 \\
6 \\
3 \\
11 \\
12 \\
24 \\
3 \\
6 \\
7 \\
3 \\
3 \\
3 \\
3 \\
3 \\
24 \\
9 \\
5 \\
5 \\
8 \\
3 \\
4 \\
4 \\
6 \\
3 \\
5 \\
4 \\
5 \\
3 \\
3 \\
3 \\
8 \\
3\end{array}$ & 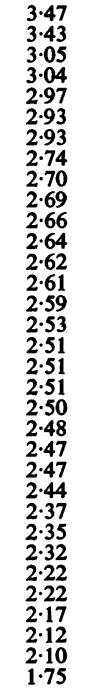 & $\begin{array}{l}\dagger \\
0 \cdot 83 \\
0 \cdot 52 \\
0 \cdot 32 \\
0 \cdot 33 \\
0 \cdot 16 \\
0.05 \\
0.03 \\
0 \cdot 13 \\
0 \cdot 27 \\
0 \cdot 66 \\
0 \cdot 10 \\
0 \cdot 29 \\
0 \cdot 19 \\
0 \cdot 08 \\
0 \cdot 28 \\
0 \cdot 19 \\
0 \cdot 22 \\
0 \cdot 19 \\
0 \cdot 44 \\
0 \cdot 28 \\
0.46 \\
0 \cdot 29 \\
0 \cdot 20 \\
0 \cdot 27 \\
0 \cdot 03 \\
0 \cdot 18 \\
0 \cdot 25 \\
0 \cdot 39 \\
0 \cdot 02 \\
0 \cdot 03 \\
0 \cdot 12 \\
0.08\end{array}$ & $\begin{array}{c}\ddagger \\
\ddagger \\
323-3,890 \\
912-1,318 \\
562-1,549 \\
606-1,096 \\
813-891 \\
446-676 \\
372-676 \\
275-871 \\
\ddagger \\
24-794 \\
78-2,239 \\
138-1,202 \\
235-646 \\
258-447 \\
235-447 \\
170-617 \\
182-575 \\
132-759 \\
60-1,514 \\
55-1,590 \\
98-891 \\
170-427 \\
52-1,047 \\
209-240 \\
107-407 \\
81-339 \\
132-209 \\
135-162 \\
107-162 \\
102-155 \\
34-93\end{array}$ \\
\hline
\end{tabular}

FS = flax plus synthetic fibre.

* mg. dust/100 m. ${ }^{3}$ air expressed as $\log _{10}$.

tEstimate unrealistic because of small number of samples.

†Estimate unrealistic because of wide scatter of concentrations.

The data relating to dust levels in pre-preparing rooms are given in Table 3 for total dust and in Table 4 for respirable dust.* In mills spinning flax plus synthetic fibres, synthetic fibres were not necessarily being handled in all rooms or at all times.

The dust concentrations (mg. dust $/ 100 \mathrm{~m}^{3}$ of air) for each sample were transformed to logarithms. The mean and standard deviations of the log. values were obtained for each of the 142 rooms. The $95 \%$ confidence limits of each mean logarithm for each room were calculated and transformed back into original units. The distribution of these 142 rooms by type of room and the level of airborne dust, expressed as mean $\log _{.10} \mathrm{mg} . / 100 \mathrm{~m}^{3}$ of air, are shown in the form of histograms in Fig. 1a for total dust and in Fig. 1b for respirable dust.

It will be seen from Fig. 1a and $b$ that there is considerable overlapping of the distribution of rooms when grouped by both total dust and respirable dust levels. In general, the dust levels in prepreparing rooms tended to be higher than those in

* Similar tables are available on request for data relating to dust concentrations in other preparing, wet finishing, and other finishing rooms. preparing rooms which, in turn, were higher than those of other finishing rooms. The wet finishing rooms were the least dusty of all. Within any one category of room there was also great variation in the range of dust levels between individual rooms, and the $95 \%$ confidence limits of mean concentrations of dust were wide even in cases where a considerable number of samples were taken in one room. This variability may be due in part to differences in the ventilation of rooms.

An opportunity to investigate the effects of improved ventilation occurred when one mill fitted new dust extraction equipment in a large preparing room in which drawing, roving, and combing processes were carried out. At the time of the first visit to this mill, when 30 samples each of total and of respirable dust were obtained, each drawing frame was fitted with a separate extraction fan which drew air from beneath the combing pins and drawing heads and discharged it into the room again through a bed of closely packed fibres which could be dismantled for cleaning. At the time of the second visit, when 19 pairs of dust samples were taken, the brush filter units had been replaced by dust extractors of the 
TABLE 4

CONCENTRATION OF AIRBORNE DUST (RESPIRABLE FRACTION) IN PRE-PREPARING ROOMS IN MILLS HANDLING FLAX ONLY OR FLAX PLUS SYNTHETIC FIBRES BY TYPE OF ROOM. ROOMS RANKED BY MEAN DUST LEVEL

\begin{tabular}{|c|c|c|c|c|c|c|}
\hline \multirow{2}{*}{$\begin{array}{l}\text { Mill No. } \\
\text { and } \\
\text { Room Code }\end{array}$} & \multirow{2}{*}{$\begin{array}{c}\text { Fibre } \\
\text { Handled }\end{array}$} & \multirow[b]{2}{*}{$\begin{array}{l}\text { Type of } \\
\text { Room }\end{array}$} & \multirow[b]{2}{*}{$\begin{array}{l}\text { No. of } \\
\text { Samples }\end{array}$} & \multicolumn{3}{|c|}{ Concentration of Airborne Dust (respirable) } \\
\hline & & & & $\begin{array}{l}\text { Mean* } \\
\text { log. }\end{array}$ & $\begin{array}{c}\text { S.D.* } \\
\text { of log. } \\
\text { Concentrations }\end{array}$ & $\begin{array}{l}95 \% \text { Confidence Limits } \\
\text { of Mean Concentrations } \\
\text { (mg. dust } / 100 \mathrm{~m}^{3} \text { air) }\end{array}$ \\
\hline $\begin{array}{rl}8 & \mathrm{D} \\
8 & \mathrm{C} \\
23 & \mathrm{C} \\
8 & \mathrm{~A} \\
13 & \mathrm{C} \\
12 & \mathrm{C} \\
2 & \mathrm{C} \\
12 & \mathrm{E} \\
2 & \mathrm{~B} \\
20 & \mathrm{C} \\
22 & \mathrm{C} \\
10 & \mathrm{C} \\
16 \mathrm{~B} \\
4 \\
\mathrm{CC} \\
12 \mathrm{~B} \\
18 \mathrm{D} \\
15 \mathrm{C} \\
4 \mathrm{~B} \\
8 \mathrm{~B} \\
13 \mathrm{~A} \\
4 \mathrm{~A} \\
18 \mathrm{C} \\
14 \mathrm{~A} \\
18 \mathrm{~B} \\
20 \mathrm{~A} \\
19 \mathrm{~A} \\
4 \mathrm{~K} \\
17 \mathrm{~B} \\
22 \mathrm{~A} \\
9 \mathrm{C} \\
14 \mathrm{C} \\
9 \mathrm{~B} \\
15 \mathrm{~A}\end{array}$ & $\begin{array}{l}\text { Flax } \\
\text { Flax } \\
\text { Flax } \\
\text { Flax } \\
\text { Flax } \\
\text { Flax } \\
\text { FS } \\
\text { Flax } \\
\text { FS } \\
\text { Flax } \\
\text { FS } \\
\text { FS } \\
\text { Flax } \\
\text { Flax } \\
\text { Flax } \\
\text { Flax } \\
\text { Flax } \\
\text { Flax } \\
\text { Flax } \\
\text { Flax } \\
\text { Flax } \\
\text { Flax } \\
\text { FS } \\
\text { Flax } \\
\text { Flax } \\
\text { FS } \\
\text { Flax } \\
\text { Flax } \\
\text { FS } \\
\text { FS } \\
\text { FS } \\
\text { FS } \\
\text { Flax }\end{array}$ & $\begin{array}{l}\text { Breaker card } \\
\text { Carding } \\
\text { Carding } \\
\text { Roughing } \\
\text { Carding } \\
\text { Carding } \\
\text { Carding } \\
\text { Combing } \\
\text { Hackling } \\
\text { Carding } \\
\text { Carding } \\
\text { Carding } \\
\text { Hackling } \\
\text { Carding } \\
\text { Hackling } \\
\text { Carding } \\
\text { Carding } \\
\text { Hackling } \\
\text { Hackling } \\
\text { Hackling } \\
\text { Piecing } \\
\text { Carding } \\
\text { Hackling } \\
\text { Hackling } \\
\text { Hackling } \\
\text { Hackling } \\
\text { Combing } \\
\text { Hackling } \\
\text { Hackling } \\
\text { Carding } \\
\text { Carding } \\
\text { Hackling } \\
\text { Hackling }\end{array}$ & $\begin{array}{r}2 \\
12 \\
3 \\
3 \\
3 \\
11 \\
24 \\
6 \\
6 \\
6 \\
7 \\
5 \\
3 \\
24 \\
5 \\
3 \\
9 \\
7 \\
4 \\
3 \\
3 \\
3 \\
4 \\
3 \\
3 \\
5 \\
9 \\
3 \\
3 \\
8 \\
3 \\
5 \\
3\end{array}$ & $\begin{array}{l}2.90 \\
2 \cdot 69 \\
2 \cdot 67 \\
2 \cdot 66 \\
2 \cdot 61 \\
2 \cdot 55 \\
2 \cdot 42 \\
2 \cdot 38 \\
2.33 \\
2.32 \\
2 \cdot 27 \\
2 \cdot 24 \\
2 \cdot 20 \\
2 \cdot 19 \\
2 \cdot 17 \\
2 \cdot 17 \\
2 \cdot 15 \\
2 \cdot 15 \\
2 \cdot 11 \\
2 \cdot 10 \\
2.09 \\
2.08 \\
2.05 \\
2.05 \\
2.02 \\
2.02 \\
2.02 \\
2.01 \\
1.99 \\
1.97 \\
1.84 \\
1.75 \\
1.68\end{array}$ & $\begin{array}{l}\dagger \\
0 \cdot 08 \\
0 \cdot 27 \\
0.05 \\
0 \cdot 21 \\
0 \cdot 24 \\
0 \cdot 21 \\
0.05 \\
0 \cdot 15 \\
0.09 \\
0 \cdot 19 \\
0 \cdot 12 \\
0.03 \\
0 \cdot 16 \\
0.03 \\
0.02 \\
0 \cdot 36 \\
0 \cdot 18 \\
0.09 \\
0 \cdot 17 \\
0.08 \\
0 \cdot 18 \\
0.23 \\
0 \cdot 10 \\
0.21 \\
0.02 \\
0.03 \\
0.08 \\
0 \cdot 13 \\
0.04 \\
0 \cdot 25 \\
0 \cdot 18 \\
0.09\end{array}$ & $\begin{array}{l}\dagger \\
440-548 \\
122-1,343 \\
226-912 \\
122-1,343 \\
244-505 \\
214-322 \\
213-269 \\
148-313 \\
137-210 \\
123-276 \\
124-247 \\
137-188 \\
132-180 \\
137-161 \\
134-161 \\
75-266 \\
96-206 \\
93-180 \\
47-330 \\
79-189 \\
43-343 \\
48-264 \\
62-200 \\
31-353 \\
98-113 \\
91-120 \\
66-158 \\
47-205 \\
86-103 \\
17-283 \\
34-93 \\
28-80\end{array}$ \\
\hline
\end{tabular}

FS = flax plus synthetic fibre.

*mg. dust $/ 100 \mathrm{~m}^{3}$ air expressed as $\log _{10}$.

†Estimate unrealistic because of small number of samples.

TABLE 5

CONCENTRATION OF TOTAL AND OF RESPIRABLE DUST IN A FLAX PREPARING ROOM BEFORE AND AFTER THE INTRODUCTION OF NEW VENTILATION EQUIPMENT

\begin{tabular}{|c|c|c|c|c|c|}
\hline \multirow[b]{2}{*}{ Type of Dust } & \multirow[b]{2}{*}{ Date } & \multirow[b]{2}{*}{ No. of Samples } & \multicolumn{2}{|c|}{$\begin{array}{l}\text { Concentration of Airborne Dust } \\
\text { (mg./100 m.s of air) }\end{array}$} & \multirow[b]{2}{*}{$\begin{array}{c}\text { Significance of Difference } \\
\text { between Mean logs. } \\
\text { (P) }\end{array}$} \\
\hline & & & Mean log. \pm S.E. & $\begin{array}{l}95 \% \text { Confidence Limits } \\
\text { of Mean log. (trans- } \\
\text { formed to } \mathrm{mg} . / 100 \mathrm{~m}^{3} \text { ) }\end{array}$ & \\
\hline Total & $\begin{array}{l}\text { June } 1961 \\
\text { Nov. } 1961\end{array}$ & $\begin{array}{l}30 \\
19\end{array}$ & $\begin{array}{l}2 \cdot 5464 \pm 0.0255 \\
2.2966 \pm 0.0243\end{array}$ & $\begin{array}{l}312-397 \\
176-223\end{array}$ & $<0.001$ \\
\hline Respirable & $\begin{array}{l}\text { June } 1961 \\
\text { Nov. } 1961\end{array}$ & $\begin{array}{l}30 \\
19\end{array}$ & $\begin{array}{l}2.0683 \pm 0.0204 \\
2.0228 \pm 0.0270\end{array}$ & $\begin{array}{r}106-129 \\
93-120\end{array}$ & $0 \cdot 1-0.2$ \\
\hline
\end{tabular}

cyclone type, one being mounted at the end of each drawing frame. The data relating to dust levels before and after ventilation changes are shown in Table 5, from which it will be seen that a significant reduction in total, but not in respirable, dust was achieved.

\section{Discussion}

A direct comparison between the dust concentration data presented in this paper and those reported by other authors is difficult because, for the reasons given, we have used the mean of the logarithms of the dust sample weights and not the actual weights as used by other authors.

We found, as in the study of the cotton industry reported by Roach and Schilling (1960) and in the study in a Massachusetts flax mill by Ferris, Anderson, and Burgess (1962), that there was a wide range of dust concentrations in each category of workroom, and that, in general, the dust concentrations were higher in the earlier processes (Fig. 1a, b). This general decrease observed in mean dust concentrations from high levels in the pre-preparing and 

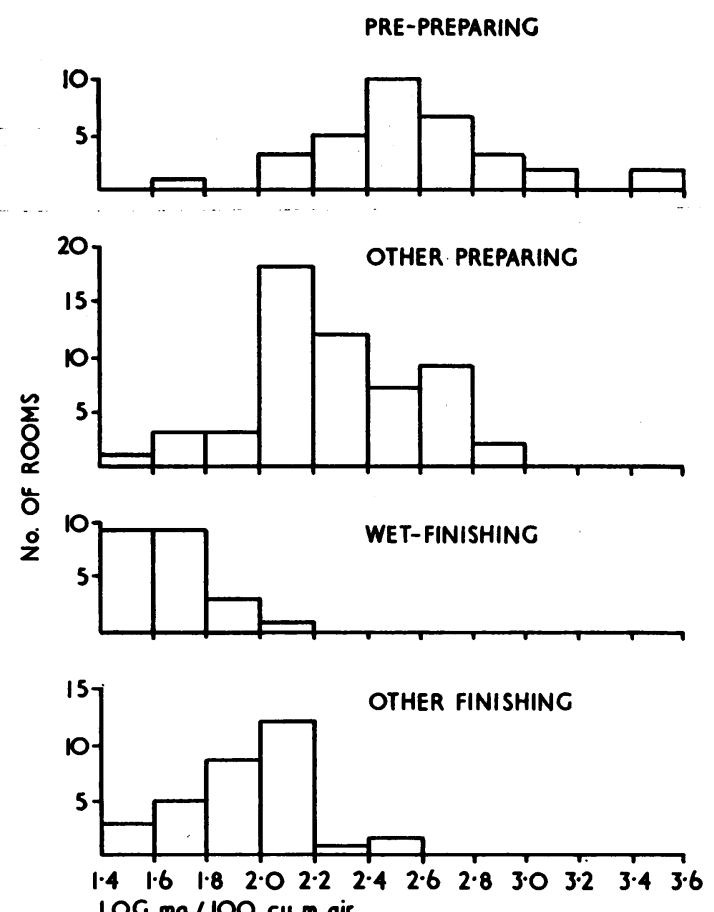

(a)

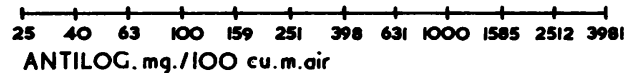

FIG. 1.-Distribution of 142 rooms in 17 flax and flax plus synthetic fibre mills by type of room and mean level of airborne dust expressed as $\log _{10} \mathrm{mg} . / 100 \mathrm{~m} .^{3}$ air: (a) total dust, (b) respirable dust.

other preparing rooms to lower levels in the finishing rooms would appear to justify the classification of workers used in the clinical survey (Elwood et al., 1965) for comparing the prevalence of byssinosis and other respiratory symptoms. In the clinical survey flax byssinosis was found to be most common among the pre-preparers and rather less common in the other preparers. It was uncommon among other finishers and negligible among wet finishers.

Figures $1 \mathrm{a}$ and $1 \mathrm{~b}$ reveal that there was a wide variation in the dust concentrations even in similar types of room. They suggest that even in the preparing processes, known to produce a lot of dust, the dust concentrations can be kept down to levels found in the cleaner finishing processes. Conversely, they confirm that rooms in which 'other finishing processes' take place can be moderately dusty. This applied particularly to winding rooms.

It is clearly highly desirable to reduce the dust levels in the preparing rooms, and it would appear from the data given that it is not too difficult to
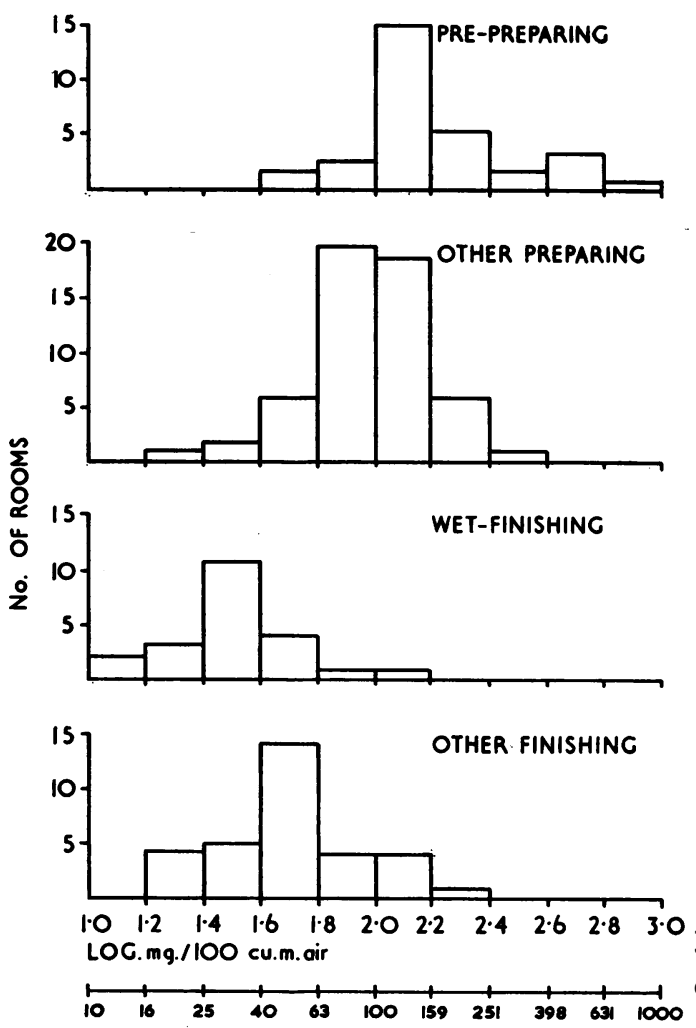

(b) achieve total dust concentrations below $200 \mathrm{mg}$./ $100 \mathrm{~m}^{3}$ of air in this type of room (Table 5). The data in Table 5, however, suggest that it may be more difficult to achieve a substantial reduction in the level of respirable dust.

This study formed part of a survey of byssinosis in flax workers undertaken at the request of the Ministry of Labour and National Insurance, The Government of Northern Ireland, which made a grant towards the cost.

We wish to thank the managements of the mills concerned for their co-operation, and Professor R. S. F. Schilling and Dr. S. A. Roach for technical advice.

We also wish to thank Professor E. A. Cheeseman for statistical advice, Mrs. E. E. Kingston and Miss T. Pitt for assistance with the analysis of data, and Miss $\mathbf{J}$. Broderick and Miss J. Smith for secretarial help.

\section{REFERENCES}

Elwood, P. C., Pemberton, J., Merrett, J. D. Carey, G. C. R., and McAulay, I. R. (1965). Brit. J. industr. Med., 22, 27. Ferris, B. C., Jr.; Anderson, D. O., and Burgess, W. A. (1962). Ibid., 19, 180

Roach, S. A., and Schilling, R. S. F. (1960). Ibid., 17, 1. 